\title{
IMPACT OF DIFFERENT TYPE OF CATTLE GRAZING ON THE PROCESSES OF AGROCHEMICAL DEGRADATION AND DIGRESSION OF SOIL COVER
}

\author{
Alexander Ragimov ${ }^{1}$, Mikhail Mazirov ${ }^{1,2}$, Vladimir Nikolaev², Aleksandra Shitikova ${ }^{2}$, and Svetlana Malakhova ${ }^{2}$ \\ ${ }^{1}$ Vladimir State University named after A.G. and N.G. Stoletov, Vladimir, Russia \\ ${ }^{2}$ Faculty of Architecture, Warsaw University of Technology, Poland
}

\begin{abstract}
The article proposes the results of studying the influence of various types of cattle grazing on the content of mobile forms of phosphorus $\left(\mathrm{P}_{2} \mathrm{O}_{5}\right)$, potassium $\left(\mathrm{K}_{2} \mathrm{O}\right)$, organic matter $(\mathrm{C}, \%)$ and $\mathrm{Ph}$ rate. It has been found out that with different types of cattle grazing, clear differentiation of the agrochemical state within the land plots is manifested. The degree of vegetation cover digression is characterized by a significant decrease in the species composition depending on the type of cattle grazing. Various levels of interrelation between the type of cattle grazing and observable dynamics of changes in the ecological functions of soil cover and their influence on the structure of the digression levels formation are designated in the article. The obtained results based on the conclusions of this article may serve as one of the options for conducting research on the assessment of destructive anthropogenic activity. For the most effective protection of soil cover of territories exposed to livestock impact, it is necessary to develop agrotechnical complexes. It has been discovered that real loads as a result of uncontrolled and periodic cattle overgrazing are 10 times higher than the maximum permissible norms that manifests itself in intense and significant violation of a natural ecosystem.
\end{abstract}

\section{Introduction}

According to official data every year, Russia loses about 2 million hectares of soil due to the degradation process. In general, almost 20 per cent of soil cover in Russia is degraded. Unregulated grazing leads to changes in vegetation cover and, as a consequence, to soil degradation and subsequent digression of soil cover. Massive soil restoration could improve the current state of affairs and and allow the use of eroded land for agriculture. Prevention of soil cover degradation and reproduction of soil fertility are urgent tasks nowadays.

The existing set of definitions of soil degradation (from Lat. Degradatio - reduction) allows us to characterize the process of soil cover disturbance only on the basis of a set of indicators and properties. Within the framework of this research, the indicators of agrochemical soil degradation and digression of vegetation cover will be analyzed based on the leading factor - grazing of cattle. Consequently, it is worth characterizing the process of soil degradation as a process of sequential deterioration of soils agrochemical properties, both in time and space, due to the constant impact of irrational livestock farming, causing not only significant decrease in soil properties, disruption of agrobicenological ties, but also complete disruption the structure of the entire agricultural landscape.

Soil dehumification is the most significant change resulting from overgrazing. This is due to the fact that overgrazing in the ecosystem significantly changes the biological cycle in the agroecosystem. Most of the aboveground phytomass does not enter the sphere of humification, since it is eaten by animals. Despite the fact that a part of organic matter enters the soil with animal excrement, no compensation occurs. In addition, excrement is unevenly distributed throughout the pasture area. Uncontrolled grazing leads to the fact that the soil is depleted of nutrients.

At pasture area grazing digression is manifested, first of all, by the disappearance of tall plants, which are usually more hygrophilous or shade-tolerant compared to others, which is explained primarily by soil compaction, drying it out, increasing sun illumination of plants due to rarefaction of grass stand during pasturing. In this case, the most radical changes are observed in the floristic composition of pasture area under the influence of grazing of plants by animals. All things being equal, taller plants will first of all be subject to digression processes. With frequent alienation of vegetation, tall plants are the first to drop out of grass stand of pasture areas, and low plants, without meeting any competition, develop better, and the grass stand of pasture becomes shorter. In the structure of soil and vegetation cover during the development of the digression process plants begin to predominate, in which the leaves are mainly located in the lower part of the shoots - grassroots plants. On the basis of many years of research, a number of 
scientists have come to the conclusion that the historical process in the use of pastures in world practice took place in the following sequence: unsystematic pasture $\rightarrow$ large-range pasture $\rightarrow$ small-area pasture $\rightarrow$ portioned pasture.

A number of authors, studying the effect of grazing on different types of soils, emphasize a common feature, namely a change in the chemical properties of soil on pastures occurs against the background of decrease in humus. The data of long-term studies on the agrochemical composition of soils of a project area show significant changes in the content of the main indicator of fertility - humus and other indicators.

The purpose of the study is to analyze the development of agrochemical degradation and the development of soil cover digression as a result of various types of cattle grazing on sod-podzolic soils of Vladimir region.

The research objectives are:

1. To analyze the rate of load on soil cover of the pastures, depending on different levels of cattle grazing;

2. To conduct a study of the agrochemical state of soil cover of the pastures for cattle grazing;

3. To assess the impact of different types of cattle grazing and the development of agrochemical degradation and digression of soil cover

\section{Methods and objects of researches}

The study was carried out on the territory of Melenkovsky district, located in the southeast of Vladimir region. The objects of research are land plots, represented by various types of cattle grazing. The first land plot is the soil cover of the near-farm territory of the agricultural enterprise Dmitrievy Gory, where there is corralled cattle grazing. The land plot has the following coordinates: $55.248222,41.778592$. The soil cover of this territory is represented by agro-soddy-podzolic light loamy soil on moraine loam with a complete absence of vegetation, with the exception of the marginal areas of the corral territory, where single specimens of vegetation of various botanical composition are observed. The second land plot is a land plot near Bolshoi Sanchur village, where free cattle grazing is observed. The land plot has the following coordinates: 55.181975, 41.767795. The soil cover of this territory is represented by agro-soddy-podzolic light loamy soil on moraine loam, with a developed vegetation cover with desertified areas occurring. The third site chosen for the study is the soil cover of haymaking area, where the influence of cattle is absent. The land plot has the following coordinates: $55.177825,41.765392$. The soil cover of this territory is represented by agro-soddy-medium podzolic light loamy soil on moraine loam with welldeveloped vegetation, which is represented by cereals and legumes, sedges, as well as forbs.

All objects of the study are characterized by warm summers and moderately cold winters with a stable snow cover. The average rainfall for the year is $560 \mathrm{~mm}$. The average amount of precipitation during the active growing season has averaged $285 \mathrm{~mm}$, which is characterized by sufficient moisture. In terms of terrain, the study areas represent a flat, gentlyundulating flat area. Parent rocks are mainly represented by moraine deposits, and there are also quaternary glacial deposits. Such factors as high acidity, low content of organic matter and silty particles, and lack of nutrients determine low natural soil fertility.

The research program included the study of the land agrochemical state and the determination of the process of vegetation cover digression according to generally accepted methods. The soil acidity rate $(\mathrm{pH})$ has been determined in $\mathrm{KCl}$ extract. The content of the labile phosphorus $\left(\mathrm{P}_{2} \mathrm{O}_{5}\right)$ and potassium $\left(\mathrm{K}_{2} \mathrm{O}\right)$ has been determined by Kirsanov's technique in modification of CINAO, the same of organic matter $(\mathrm{C}, \%)$ - by Tyurin's technique in modification of CINAO.

The amount of digression has been defined by quantifying the type of vegetation based on the registration of individual groups of plants using the framework method by counting the number of plants per 1 sq.m with subsequent interpretation for the territory total area.

\section{Results and their discussion}

Changing the type of cattle grazing entails negative changes in a number of important agrochemical soil indicators. As a result of the study, accurate definite territorial differentiation of agrochemical parameters distribution in the territories subject to different cattle grazing was revealed. Table 1 presents the average data on the agrochemical state of land plots subject to various cattle grazing.

Distribution of $\mathrm{pH}$ rate indicators made it possible to reveal a certain differentiation within each land plot subject to different cattle grazing. Thus, in the area with the corralled method of grazing it has been established that in the central part of the corral territory, two territorial subplots of the same type may be distinguished with average soil acidity ranged from 4.8 to $5.1 \mathrm{pH}$ units. With the distance from the center of the corral, $\mathrm{pH}$ rate is $5.4 \mathrm{pH}$ units. The rate of soil acidity in the corral area in average is $4.91 \mathrm{pH}$ units. Thus, the central part of the analyzed area is characterized by the lowest acidity indicators at the corralled cattle grazing, that is caused by increased concentration of livestock, as well as by release of liquid organic waste, which significantly affects the rate of soil acidity. In the area with free cattle grazing $\mathrm{pH}$ rates are lower compared to the corralled grazing method.

Differentiation of soil acidity is due to the nonuniform distribution of the cattle livestock in view of the natural and territorial location and constantly changing distribution of the cattle population. In this case, the regulating factor of cattle livestock distribution at free grazing is the need for the favorable places, such as shade from forests, wind protection, proximity to watering places, etc. Based on the study results, it has been found out that in the areas where the livestock population is the most intensively concentrated in the process of free grazing, the soil acidity rate averages 
Table 1.Agrochemical state of land plots subject to various cattle grazing.

\begin{tabular}{|l|c|c|c|c|c|}
\hline \multicolumn{1}{|c|}{ Walking type of cattle } & $\mathbf{p H}$ & $\mathbf{N}$ & $\mathbf{C}$ & $\mathbf{P}_{2} \mathbf{O}_{\mathbf{5}}$ & \multicolumn{1}{|c|}{$\mathbf{K}_{\mathbf{2}} \mathbf{O}$} \\
\cline { 4 - 7 } & & \multicolumn{2}{|c|}{ per cent } & \multicolumn{2}{|c|}{$\mathbf{~ m g / ~} \mathbf{k g}$} \\
\hline Area № 1. Corralled type of cattle grazing & 4.91 & 0,85 & 1.16 & 73.3 & 61.8 \\
\hline Area № 2. Free type of cattle walking & 5.97 & 0.33 & 1.30 & 104.8 & 121.1 \\
\hline Area № 3. No cattle grazing (hayland) & 6.03 & 0.14 & 2.22 & 125.1 & 141.4 \\
\hline
\end{tabular}

Table 2.Score of vegetation cover digression and distribution of botanical composition on land plots subject to different cattle grazing.

\begin{tabular}{|c|c|c|c|c|c|}
\hline \multirow[t]{2}{*}{ Walking type of cattle } & \multirow{2}{*}{$\begin{array}{l}\text { Digression } \\
\text { score }\end{array}$} & Cereals & Legumes & Sedge & Herbs \\
\hline & & \multicolumn{4}{|c|}{ per cent } \\
\hline Area № 1. Corralled type of cattle grazing & 8.4 & 9.5 & 5.1 & 3.9 & 2.9 \\
\hline Area № 2. Free type of cattle grazing & 4.7 & 59.2 & 29.6 & 27.1 & 24.8 \\
\hline Area № 3. There is no cattle grazing (hayland) & 2.2 & 82.3 & 40.6 & 37.5 & 35.4 \\
\hline
\end{tabular}

$5.97 \mathrm{pH}$ units. This rate is $5.5 \mathrm{pH}$ units in the places of constantly changing grazing position and feeding places, in the places of periodic exposure from cattle the acidity index is $6.4 \mathrm{pH}$ units. Acidity indicators in this area vary from 5.2 to $6.6 \mathrm{pH}$ units. On the territory where there is no cattle grazing, no clear differentiation of soil acidity rate is revealed, and that is characterized mainly by absence of cattle grazing, as well as by heterogeneity of the soil and lithological composition of the territory. Acidity indicators in this area vary from 5.3 to $6.7 \mathrm{pH}$ units and averages $6.03 \mathrm{pH}$ units.

The distribution of mobile forms of $\mathrm{P}_{2} \mathrm{O}_{5}$ and $\mathrm{K}_{2} \mathrm{O}$ is also due to the presence of clear differentiated structure.

So, with the corral type of cattle grazing there is a focal distribution of mobile forms of $\mathrm{P}_{2} \mathrm{O}_{5}$ and $\mathrm{K}_{2} \mathrm{O}$. In the central part of the corral area, the content of $\mathrm{P}_{2} \mathrm{O}_{5}$ and $\mathrm{K}_{2} \mathrm{O}$ is $70.5 \mathrm{mg} / \mathrm{kg}$ of soil and $82 \mathrm{mg} / \mathrm{kg}$ of soil, respectively. At the distance from the center the average $\mathrm{P}_{2} \mathrm{O}_{5}$ content is $78.0 \mathrm{mg} / \mathrm{kg}$ of soil, while the $\mathrm{K}_{2} \mathrm{O}$ content is $72 \mathrm{mg} / \mathrm{kg}$ of soil, and closer to the edges of the studying area the rate of $\mathrm{P}_{2} \mathrm{O}_{5}$ is $85 \mathrm{mg} / \mathrm{kg}$ of soil and the rate of $\mathrm{K}_{2} \mathrm{O}$ is $79.5 \mathrm{mg} / \mathrm{kg}$ of soil. The range of variation of the $\mathrm{P}_{2} \mathrm{O}_{5}$ content is from 67 to $87 \mathrm{mg} / \mathrm{kg}$ of soil and the same of $\mathrm{K}_{2} \mathrm{O}$ is from 62 to $82 \mathrm{mg} / \mathrm{kg}$ of soil. The average content of mobile forms of $\mathrm{P}_{2} \mathrm{O}_{5}$ and $\mathrm{K}_{2} \mathrm{O}$ in the area with the corral method of cattle grazing is $73.3 \mathrm{mg} / \mathrm{kg}$ of soil and $61.8 \mathrm{mg} / \mathrm{kg}$ of soil, respectively. Consequently, it becomes obvious that the lowest rates of $\mathrm{P}_{2} \mathrm{O}_{5}$ and $\mathrm{K}_{2} \mathrm{O}$ mobile forms sufficiency during corralled cattle grazing are characteristic of the central part of the corral plot.

The analysis of the area where free cattle grazing takes place has shown that the level of mechanical impact is significantly less in comparison with the corralled method of grazing. Thus, it has been stated that, just as in soil acidity, there is a difference in places where slight impact by cattle occurs, and the rate of $\mathrm{P}_{2} \mathrm{O}_{5}$ and $\mathrm{K}_{2} \mathrm{O}$ is $93 \mathrm{mg} / \mathrm{kg}$ of soil and $125.5 \mathrm{mg} / \mathrm{kg}$ of soil. In the places of grazing and feeding the content of $\mathrm{P}_{2} \mathrm{O}_{5}$ and $\mathrm{K}_{2} \mathrm{O}$ is $101.5 \mathrm{mg} / \mathrm{kg}$ of soil and $120.5 \mathrm{mg} / \mathrm{kg}$ of soil, in places of periodic exposure this rate is $108.5 \mathrm{mg} /$ $\mathrm{kg}$ of soil and $112.5 \mathrm{mg} / \mathrm{kg}$ of soil, respectively. In general, the rate of $\mathrm{P}_{2} \mathrm{O}_{5}$ in this area varies from 89 to $111 \mathrm{mg} / \mathrm{kg}$ of soil. Whereas the variation of $\mathrm{K}_{2} \mathrm{O}$ is from 106 to $128 \mathrm{mg} / \mathrm{kg}$ of soil. The average content of
$\mathrm{P}_{2} \mathrm{O}_{5}$ and $\mathrm{K}_{2} \mathrm{O}$ is $104.8 \mathrm{mg} / \mathrm{kg}$ soil and $121.1 \mathrm{mg} / \mathrm{kg}$ soil.

In the area where cattle grazing is absent (in the central part of the studying area), the content of $\mathrm{P}_{2} \mathrm{O}_{5}$ and $\mathrm{K}_{2} \mathrm{O}$ is $129.5 \mathrm{mg} / \mathrm{kg}$ of soil and $145 \mathrm{mg} / \mathrm{kg}$ of soil, closer to the edges the rates average $122.5 \mathrm{mg} / \mathrm{kg}$ of soil and $138.5 \mathrm{mg} / \mathrm{kg}$ of soil, there is also a site where the $\mathrm{P}_{2} \mathrm{O}_{5}$ index averages $113.5 \mathrm{mg} / \mathrm{kg}$ of soil and 130 $\mathrm{mg} / \mathrm{kg}$ of soil. The average content of $\mathrm{P}_{2} \mathrm{O}_{5}$ and $\mathrm{K}_{2} \mathrm{O}$ is $125.1 \mathrm{mg} / \mathrm{kg}$ of soil and $141.4 \mathrm{mg} / \mathrm{kg}$ of soil. $\mathrm{P}_{2} \mathrm{O}_{5}$ rates in this area vary from 110 to $132 \mathrm{mg} / \mathrm{kg}$ soil. These indicators are mainly due to the heterogeneity of soil and lithological composition of the studying area and the level of intensification and soil treatment.

The content of organic matter in soil and its main component, humus, is the main factor in assessing soil fertility.

Many scientific studies show that humic substances play a leading role in the large geological cycle, taking an active part in the destruction of rocks and biological weathering. As a result of the study a certain territorial differentiation of soil organic matter distribution has been revealed on the territories subject to various types of cattle grazing. It has been determined that on the territories where paddock grazing takes place a clear differentiation of the organic matter content is observed. Thus, in the central part of the paddock area the organic matter content is 1.1 per cent. At the distance from the center the average organic matter content is 1.3 per cent. Closer to the edges of the area under study the organic matter content is 1.5 per cent. It has been established that the organic matter content of in the area with a paddock type of cattle grazing varies from 0.98 to 1.5 per cent.

In the area where free cattle grazing takes place the level of mechanical impact is much lower in comparison with the corralled grazing method. So, the rate of organic matter is 1.2 per cent in the places of rest for cattle. In places of grazing and feeding the abovementioned rate is 1.5 per cent. In the places of periodic exposure from cattle the organic matter content is 1.8per cent. The rates of organic matter in the area with free grazing vary from 1.0 to 1.8 per cent.

On the territory where there is no cattle grazing, no clear differentiation of the organic matter rate has been registered. Organic matter indices in this area vary from 
2.08 to 2.32per cent. As a result, the average rates of the organic matter content have been defined depending on the type of cattle grazing, which are 1.16per cent for the corral type of cattle grazing, 1.30per cent for the free type of cattle grazing, and 2.22per cent for no cattle grazing (haymaking) type.

On the basis of the research done, we can say that the distribution of the organic matter content rate depends on the type of cattle grazing and the level of its load, mechanical impact on the soil cover, as well as the soil and lithological composition of the territory.

Unregulated grazing is one of the reasons for the change of vegetation cover, deterioration of the soil physical properties and as a result of soil degradation. This phenomenon is called pasture digression. . As a result of the research done, there has been discovered a certain territorial distribution of vegetation cover digression score differentiation in areas subject to different types of cattle grazing. The data are given in Table 2.

It has been found out that on the territory subject to corralled cattle grazing, there is a clear differentiation of the digression score distribution value. On the territory of closed cattle grazing it has been defined that in the center the average rate of the vegetation cover digression score distribution is 9.5 , further on, at the distance from the center the digression score is 7.1, and at the edges of the study area this rate is 5.3. Digression scores in this area range from 4.8 to 10.2. Thus, the most exposed part of the territory for closed cattle grazing is its central part due to the increased concentration of livestock. In the area where free cattle grazing takes place, the level of mechanical impact is significantly less in comparison with the corralled grazing method. Differentiation of the digression score rate in this case is due to the nonuniform distribution of the cattle population due to the natural and territorial location. The digression score is 6.2 in the places of periodic impact from cattle, in the places of grazing and feeding it is 4.7 , while in the places of periodic impact from the cattle density is 2.5 . Digression scores in this area range from 1.8 to 7.2.

On the territory not subject to cattle grazing, no clear differentiation of the digression score rate is revealed. The digression score indices in this area vary from 1.9 to 4. As a result, the average change in the digression score of the vegetation cover is established depending on the type of cattle grazing. At corralled cattle grazing the average rate of the digression score is 8.4. This stage of digression is half-poaching, characterized by a rare occurrence of tall-growing grasses, since perennial weeds begin to displace pasture grasses. Emergence of weedy annuals, such as knotweed, bluegrass, is observed. This indicator is explained by the limited and closed territory where grazing takes place, as well as by the increased concentration of livestock. The average digression score is 4.7 at free cattle grazing. The stage of pasture digression is semi-pasture, and is characterized by the loss of indigenous forbs and appearance of pasture weeds. Tall-growing grasses are inferior to lowgrowing ones. This rate is associated with heterogeneity of livestock distribution, as well as the unlimited area where grazing takes place. In the area where cattle grazing is absent the average digression score is 2.2. This stage of digression is the initial haymaking, characterized by a high grass stand, where, together with broad-leaved forbs, hay-type tall-growing grasses prevail. This indicator is explained by absence of animal impact, minimal mechanical impact of agricultural machinery on the soil cover, as well as heterogeneity of the soil and lithological composition of the territory.

Based on the research done, it may be stated that the digression score distribution depends on the type of cattle grazing and the level of its load, mechanical impact on the soil cover, as well as the soil and lithological composition of the territory.

The pasture vegetation cover at the moment is due to rather sparse herbage, mainly consisting of droughtresistant plant species. Vegetation at these pastures is represented mainly by such species as camel thorn and bulbous bluegrass. Cereals and legumes are present to a lesser extent. As a result of the research done, the vegetation cover botanical composition in the territories subject to various cattle grazing is defined. The area where cattle grazing takes place is characterized by minimal vegetation content.

The botanical composition of the territory for corralled cattle grazing is represented mainly by cereals, which make up 45per cent of the total amount of all vegetation. This indicator is determined by the highest resistance to mechanical degradation factor. In addition the botanical composition is characterized by the content of legumes, which make up 24per cent of the total, and the content of sedges and herbs, which make up 18per cent and 13per cent of the total, respectively. These indicators are due to the lowest resistance to mechanical degradation factor. The territory where free cattle grazing occurs is characterized by a lower level of mechanical impact, as well as by increased content of vegetation in comparison with corralled grazing. The botanical composition of the territory for free grazing is represented mainly by cereals, which make up 42per cent of the total amount of all vegetation. This indicator arises from the highest resistance to mechanical degradation factor. In addition to this, the botanical composition is characterized by the content of legumes, which make up 21per cent of the total, and the content of sedges and herbs, which make up 19per cent and 18per cent of the total amount, respectively. These indicators are due to the lowest resistance to mechanical degradation factor.

The area where there is no grazing of cattle is characterized by high content of vegetation in comparison with free grazing. It has been established that the botanical composition of the territory in the absence of cattle grazing is represented by both cereals and legumes, which make up 28per cent and 26per cent of the total amount of all vegetation, respectively, and the content of sedges and herbs, which make up 23per cent of the total. These indicators are determined by the lack of cattle grazing and minimal mechanical impact.

As a result, the changes in the botanical composition are defined depending on the method of cattle grazing (Table 2). The botanical composition is represented mainly by cereals for corralled grazing. As the 
mechanical degradation factor decreases, leveling of the botanical composition of the study area is observed. In the area where cattle grazing is absent and the mechanical impact is minimal, the content of cereals, legumes, sedges and herbs is approximately equal and amounts to 40.6per cent, 37.5per cent, 35.4per cent, 35.4per cent, respectively.

\section{Conclusion}

As a result of the study it has been stated that under the conditions of different cattle grazing, there is a clear and differentiated distribution of agrochemical indicators that cause agrochemical degradation of soil cover. Thus, the most pronounced agrochemical degradation has been revealed on a land plot with a corral type of cattle grazing, where the rate of the anthropogenic load on the soil cover of the pasture area is maximum in comparison with free cattle grazing, as well as on the territory where cattle grazing is absent. There is a sharp decrease in the content of organic matter, mobile forms of phosphorus and potassium, as well as a fairly high level of soil acidity on this territory. It has been also found out that in the area with the corral type of grazing of cattle territorial distribution of degraded areas occurs. The territory where cattle grazing takes place is also characterized by low agrochemical indicators and unfavorable agrophysical state in comparison with the free range of cattle. However, gradual increase in the agrochemical state is established, which is caused by changes in anthropogenic impact due to the constant dynamics of cattle population in the system of soil and landscape use of territory. On the territory where cattle grazing is absent only a slight differentiation of agrochemical properties has been registered, which is due to the level of fertilizers use, soil treatment and soil and lithological structure of the site.

The degree of pasture digression of soil cover is directly proportional to the level of agrochemical degradation. It is found out that in the case of corral cattle grazing the level of vegetation digression is represented by half-poaching, which is characterized by a rare occurrence of tall-growing grasses or a complete absence of vegetation. As the degree of cattle grazing changes, the structure of vegetation cover alternates due to a change in the digression score towards semi-grazing digression, which is manifested by the loss of native forbs and the appearance of pasture weeds on the site with free cattle grazing. In the area where cattle grazing is absent the level of soil digression is minimal and represents the initial hayfield, characterized by high grass stand, where, together with broad-leaved forbs, hay-type tall-growing grasses prevail. Thus, the choice of cattle grazing type regulates the processes of agrochemical soil degradation with a subsequent influence on the processes of vegetation cover digression.

\section{References}

[1] A. Sorokin, A. Bryzzhev, A. Strokov, A. Mirzabaev, T. Johnson, S.V. Kiselev, The Economics of Land Degradation in Russia, Economics of Land Degradation and Improvement - Global Assessment for Sustainable Development, 541-576 (2015)

[2] M.L. Stein, Interpolation of spatial data: some theory for kriging (New York, Springer, 2012) 247

[3] B. Minasny, A.B. McBratney, A.E. Hartemink, Global pedodiversity, taxonomic distance, and the World Reference Base, Geoderma 155, 3-4, 132-139 (2010)

[4] I.C. Burke, W.K. Lauenroth, R. Riggle, P. Brannen, B. Madigan, S. Beard, The important relative of grazing, topography microsite and in patterns controlling spatial - spatial plant species of soil properties in the shortgrass variability steppe, Ecosystems, 422-438 (1999)

[5] T.A. Arkhangelskaya, M.V. Prokhorov, M.A. Mazirov, Annual temperature dynamics of arablesoils of vladimiropolyepaleocryogenic complexes, Earth's Cryosphere 12, 3, 80-86 (2008)

[6] E. Laringson, L. Talgre, Problems of abandoned fields, Agronomy Research 1, 63-67 (2003)

[7] E.V. Shein, V.I. Kiryushin, A.A. Korchagin, et al., Assessment of agronomic homogeneity and compatibility of soils in the Vladimir Opolie region, Eurasian Soil Sc. 50, 1166-1172 (2017) DOI: 10.1134/S1064229317100118

[8] Oliver Kiptoo Kirui, Alisher Mirzabaev, Economics of land degradation in Eastern Africa, ZEF Working Paper Series 128, 29 (2014)

[9] E. Nkonya, N. Gerber, P. Baumgartner, J. von Braun, A. De Pinto, V. Graw, E. Kato, J. Kloos, T. Walter, The Economics of Land Degradation: toward an integrated global assessment, ZEF Discussion Papers on Development Policy 150, 184 (2011b)

[10] O. Naumova, I. Svetkina, M. Tyugin. Problem Analysis of Agriculture Development in Russia, IOP Conference Series: Earth and Environmental Science 459, 062066 (2020) DOI: 10.1088/17551315/459/6/062066

[11] H.B. Nayakekorale, Soil Degradation (2020) DOI: 10.1007/978-3-030-44144-9_9

[12] Ahmet Cilek, Erhan Akça, Cenk Donmez, Mehmet Akif Erdoğan, Burcak Kapur, Selim Kapur, Soil Degradation: Global Assessment (2020) DOI: 10.1201/9780429346255-28

[13] Michael Zoebisch, Eddy Pauw, Soil Degradation: Food Security (2020) DOI: 10.1201/9780429445552-29

[14] T.A. Arkhangel'skaya, M.A. Butylkina, M.A. Mazirov, et al., Properties and functioning of arable soils of the paleocryogenic soil complex in the Vladimir opolie region, Eurasian Soil Sc. 40, 237-246 (2007) DOI: 10.1134/S1064229307030015 